\title{
WHOLE BODY CRYOTHERAPY AND ADAPTIVE REACTIONS OF THE HUMAN ORGANISM IN THE ASPECT OF COMPLEX SYSTEM THEORY
}

\author{
Giedrè Taletavičiene் $\dot{1}^{1,2}$, Alfonsas Vainoras ${ }^{2}$, Kristina Berškienè $\dot{2}^{2}$ Kęstutis Ramanauskas ${ }^{3}$ \\ Health and Leisure Center of Druskininkai, Health Resort Druskininkai Division ${ }^{l}$, \\ Druskininkai, Lithuania \\ Lithuanian University of Health sciences ${ }^{2}$, Kaunas, Lithuania \\ Lithuanian Health Resort Science and Research Center ${ }^{3}$,Vilnius, Lithuania
}

\begin{abstract}
Research background and hypothesis. The research focuses on changes of different ECG parameters and their concatenations during the whole body cryotherapy procedure.

Research aim was to evaluate the changes in the relationships and complexity of the human organism systems by analyzing different ECG parameters and their dynamical concatenations during the whole body cryotherapy procedure.

Research methods. The sample included 24 volunteers without cardiovascular diseases who received whole body cryotherapy treatment course which consisted of 7 procedures per person on average. The 12-lead standard ECG was registered using computerized ECG analysis system "Kaunas-Load". ECG was registered continuously 1 min before, during the procedure and 3 min after the procedure.

Research results. Regulatory system is activated on all fractal levels during cryotherapy procedure. This is reflected by changes of measured durational parameters: RR, JT, dQRS. Significant changes in the supplying system (ST segment position) were not observed. Significant changes of metabolic processes (T-wave amplitude) at organ and cell levels can be observed during the recovery after the procedure. Changes in ECG parameter concatenations show that first the regulatory system reacts on the organism level (RR/JT), neurohumoral system is activated during the procedure and interactions between systems (RR/dQRS) and interactions in the organ and cell levels (JT/dQRS) increase during the recovery period after the procedure.

Discussion and conclusions. Whole body cryotherapy causes changes in ECG parameters and their concatenations which represent adaptive organism reactions and activation of all organism adaptive resources. The data show the safety of the procedure from the coronary, as well as hemodynamic point of view of other organs.
\end{abstract}

Keywords: cryotherapy, complex system theory, concatenation between ECG parameters.

\section{INTRODUCTION}

$\mathrm{C}$ ryotherapy [kryos - cold, therapy - treatment (gr.)] - is a method of physiotherapy treatment, that is based on using cold, as the main physical factor impacting human's body's surface. Cryotherapy is cooling of whole organism or parts of it with extremely cold gases $\left(-130,-160^{\circ} \mathrm{C}\right)$.

Pioneer of cryotherapy Japanese physician Tosimo Jamauchi started to apply this method to treat rheumatoid arthritis in 1978. Since 1985, cryotherapy was introduced in Germany, and in 1989 - Poland (Sieron, Ciesar, 2007 a). Cryotherapy is now widely used in Europe in Germany, Poland, Russia, Ukraine, Czech Republic, Latvia and others. In Lithuania cryotherapy as a therapeutic procedure is known to few, it was introduced in 2005. Lithuania is only just starting to investigate the effectiveness of the procedure and the impact of it on a human body. 
Versatility and high therapeutic efficacy of cryotherapy as physiotherapy procedure, determine the spreading of this method into all areas of medicine, as well as in sports medicine. The primary goals of cryotherapy in sports medicine - traumatic pain reduction, activation of regeneration processes, toning, and fatiguereducing effects of cryotherapy. It has been shown that with the use of cryotherapy, it is possible to improve athletes' performance. Cryotherapy has a non-specific stimulatory effect, activates the body's self-repairing reactions. In some cases, the same technique of cryotherapy can be used to treat two opposite diseases, such as allergy and immune deficiency-cryotherapy returns to normal immune system activity (Апрелева, Баранова, 2007).

Effects of cryotherapy are studied in different aspects. Its efficiency for the treatment of various diseases can be evaluated by surveys and tests, also by monitoring changes of various biochemical indices. In sports medicine cryotherapy is studied for the better understanding of its impact on a common well-being of athletes and their exercise tolerance (Joch, 2004).

Majority of research results suggest, that the mechanism of cryotherapy effect is based on stressogenic reactions, in the body i. e. result of the activation of adaptive resources of all major body systems - thermoregulatory, immune, endocrine, cardiovascular, respiratory, neurohumoral (Lyakh et al., 2009).

Adaptive processes in the human body can be evaluated on the basis of complex systems theory. Complex system science is a field of science that deals with the general properties of systems, which are treated as complex in its nature/character, organization and management (Erdi, 2008), i. e. science that deals with how the links of separate parts of system impacts behavior of all system and how the system interacts with the environment (the scope of complex system in medicine is called "Systems medicine", in biology -"Systems biology").

In this respect there are several holistic systems in the human body: skeletal - muscle system (we call it peripheral system - P), cardiovascular system (supplying system - S) and regulatory system (R). These three systems are called holistic because they interact with every cell in the human organism. When organism adapts to the changing environment, all three systems react in conjunction (during every adaptation in different form and degree) and a whole body reaction is always a result of cumulative responses of these three systems
(Berškienė, 2010). There are functional synergistic relationships (interactions) among these systems, so the body works as one integral unit. The developed model helps to evaluate the integrity of the body and reveals the essential functional relationships (Vainoras et al., 2008).

Human body systems can be analyzed at different levels of complexity (molecules, cells, tissues, organs, systems), and physiological data analyzed on several levels show the complexity, fractality, interrelations and dynamic links in the system.

Speaking about the human body as a complex system and its properties, the main system which affects the functionality of whole organism at many levels, is the cardiovascular system. Looking at the human body as an adaptive integrated system, cardiovascular system is a "convenient" system, which interacts with all systems in the organism and represents all its functionality with electrical processes (ECG) (Berškienè, 2010). ECG represents the functioning of the heart at all its levels: heart rate variations (RR) well characterize regulatory processes, cardiac electrical systole duration (JT) is related to cardiac metabolic processes (lower level of complexity - process duration is up to $500 \mathrm{~ms}$ ). Shorter processes, such as QRS complex duration (dQRS), characterize regulatory cardiac conduction system processes (duration up to $100 \mathrm{~ms}$ ) (Žemaityté, 1997). It is important to evaluate not only ECG parameters, but also the changes of their concatenations also, which reflects not only changes at certain levels, but also the dynamic relationships between these levels (Berskiene et al., 2009).

The aim of this study was to evaluate the changes in the relationships and complexity in the systems of the human organism which represents adaptive organism reactions by analyzing different ECG parameters and their dynamical concatenations during whole body cryotherapy procedure.

Hypotheses: $\mathrm{H}_{\mathrm{o}}$ : Whole body cryotherapy does not cause changes in ECG parameters and their concatenations. $\mathrm{H}_{1}$ : Whole body cryotherapy causes changes in ECG parameters and their concatenations.

\section{RESEARCH METHODS}

ECG parameters and their concatenations changes during cryotherapy procedure were recorded using the original ECG analysis system 
"Kaunas-Load" and reflect not only the changes in the cardiovascular system but also adaptive reactions of the whole body.

24 volunteers without the history of cardiovascular diseases participated in this study. The average age was $52.2 \pm 11.7$ (from 20 to 72 years old). There were 9 women (average age $53.3 \pm 5.5 \mathrm{y}$.) and $15 \mathrm{men}$ (average age $51.5 \pm 14.4 \mathrm{y}$.). They received whole body cryotherapy treatment course which consisted from 4 to 14 procedures, 7 procedures per person on average.

An open top personal cryosauna in which, with the aid of liquid nitrogen vapors, the $-160^{\circ} \mathrm{C}$ temperature was used for the procedures. Procedures where carried out on a daily basis. The length of the first procedure was $100 \mathrm{~s}$, and then the length of each next procedure was 5-10 s longer. The maximum exposure time was 3 minutes $(180 \mathrm{~s})$. The 12-lead standard ECG was registered using computerized ECG analysis system "KaunasLoad". ECG was registered continuously $1 \mathrm{~min}$ before each procedure, during the whole procedure and $3 \mathrm{~min}$ after the procedure.

ECG parameters where analyzed in lead II on a computer screen with the help of high sensitivity electronic ruler. Noises caused by the electrical circuit, breathing and motions where filtered using ECG filters. Parameters examined: before procedure (1), during procedure (2) and during the recovery ( 3 minutes after the procedure) period (3), interval RR (RR1, RR2, RR3), interval JT (JT1, JT2, JT3), QRS (dQRS1, dQRS2, dQRS3), amplitude ST (AST1, AST2, AST3), amplitude R (AR1, AR2, AR3) and T (AT1, AT2, AT3) wave amplitudes, and arterial blood pressure before the procedure and after it. We also evaluated concatenations of ECG parameters: RR/JT (RR/ JT1, RR/JT2, RR/JT3), JT/dQRS (JT/dQRS1, JT/ dQRS2, JT/dQRS3), RR/dQRS (RR/dQRS1, RR/ dQRS2, RR/dQRS3), R/T (AR/AT1, AR/AT2, AR/ AT3), T/ST (AT/AST1, AT/AST2, AT/AST3), R/ST (AR/AST1, AR/AST2, AR/AST3).

The data were processed using SPSS 17.0. To evaluate general changes of ECG parameters, in each test arithmetic averages of subject's ECG parameters were calculated. The pairs of ECG parameters compared were as follows: before the procedure and during the procedure, during the procedure and during the recovery period, before the procedure and during the recovery period after it, i. e. RR1-RR2, RR2-RR3, RR1-RR3, JT1-JT2, JT2-JT3, JT1-JT3 and etc., systolic and diastolic blood pressure before the procedure (1) and after it (2), i. e. SBP1-SBP2, DBP1-DBP2 and concatenations of parameters RR/JT1-RR/ JT2，RR/JT2-RR/JT3，RR/JT1-RR/JT3 etc. A continuous record of all parameters was measured in the same sections and the averages of series of cardio cycles were measured.

In the perspective of complex system theory, acting peripheral system $(\mathrm{P})$ was evaluated by pulse pressure, the Regulatory system (R) was evaluated by RR interval, and the Supplying system (S) was evaluated by JT interval. JT interval changes are directly related to the heart metabolism processes, QRS complex duration reflects the regulatory system features (conduction) of heart itself, $\mathrm{T}$ wave amplitude is connected to intrinsic heart metabolic processes.

According to normal physiology, we postulate, that interval RR (RR1, RR2, RR3), reflect the changes in regulatory system function (level of whole human organism), JT (JT1, JT2, JT3) reflect changes in metabolism of the heart, and duration QRS (dQRS1, dQRS2, dQRS3) reflect changes in the regulatory system of the heart (conduction features of the heart), ST segment amplitude (AST1, AST2, AST3) reflects the effectiveness of coronary blood supply, R wave amplitude (AR1, AR2, AR3) and T wave (AT1, AT2, AT3) amplitudes are connected to intrinsic heart metabolic processes.

Concatenations of ECG parameters, intervals $\mathrm{RR} / \mathrm{JT}$ (RR/JT1, RR/JT2, RR/JT3), reflects interrelations between regulatory and heart metabolic processes (whole organism level), JT/ dQRS (JT/dQRS1, JT/dQRS2, JT/dQRS3) reflect interrelations between heart metabolic processes and intrinsic heart regulatory processes (sub systemic level), RR/dQRS (RR/dQRS1, RR/ dQRS2, RR/dQRS3) reflect concatenation between two fractal levels - the organism and the subsystem.

We have investigated concatenations and other amplitude parameters, but their physiological interpretation still is not clear, AR/AT (AR/ AT1, AR/AT2, AR/AT3) could be related to the breathing effectiveness, AT/ST (AT/AST1, AT/ AST2, AT/AST3) could be related to the coronary hemodynamic, AR/AST (AR/AST1, AR/AST2, AR/AST3) could be connected to the interrelation between the breathing system and the effectiveness of coronary hemodynamic.

The normality of distribution of results was estimated using the Shapiro-Wilk test. The data 
differed significantly from the normal distribution. In order to determine the significance of the differences between the examinations before, during and after the whole-body cryotherapy, nonparametric Wilcoxon test for paired samples was used. The significance level $\mathrm{p}<0.05$.

The study was carried out with Kaunas Regional Biomedical Research Ethics Committee Permission No. BE-2-50.

\section{RESEARCH RESULTS}

Durational and amplitude parameters and inter-parametric concatenation sample differences before cryotherapy procedure, during the procedure and during the recovery period after the procedure were assessed. All measured durational parameter values increased during the procedure and after it, but statistically significant differences $(\mathrm{p}<0.05)$ occurred only during recovery, i. e. soon after procedure (Figure $1 \mathrm{a}, \mathrm{b}, \mathrm{c}$ ).

Amplitudinal parameters changed slightly differently. R-wave amplitude (AR) statistically significantly increased during the procedure $(\mathrm{p}<0.05)$, statistically significantly decreased after the procedure $(\mathrm{p}<0.05)$ and recovered its initial state soon after that, i. e. there were no statistically significant difference between R-wave amplitude before the procedure and after it $(\mathrm{p}>0.005)$ (Figure 2 a). T-wave amplitude, like durational parameter
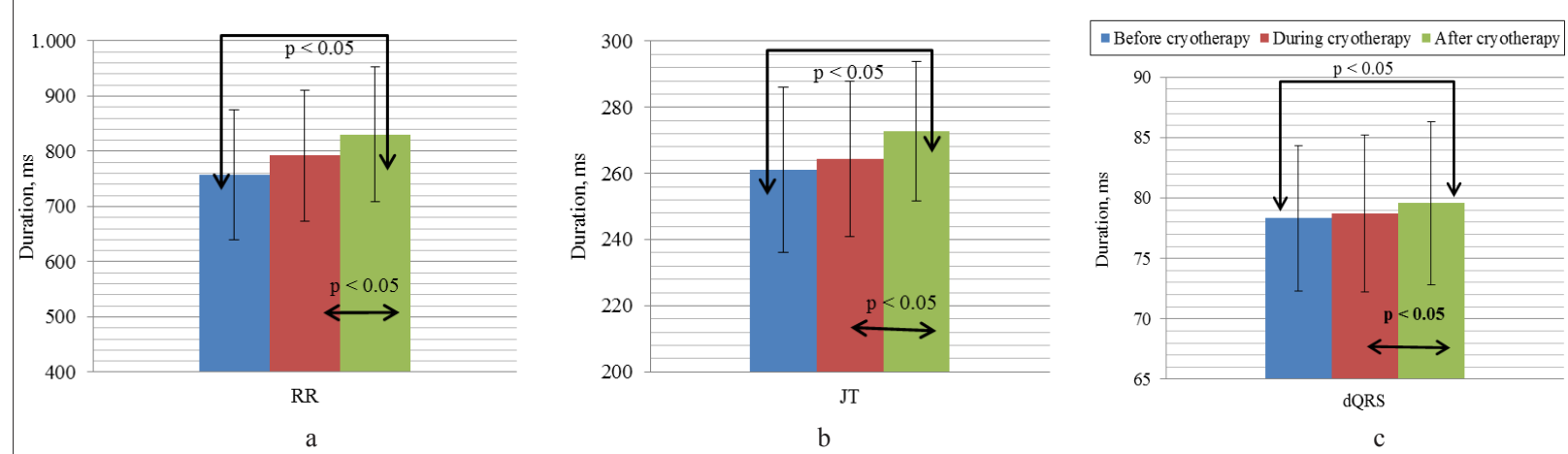

Figure 1. Changes in the duration of ECG parameters during whole body cryotherapy

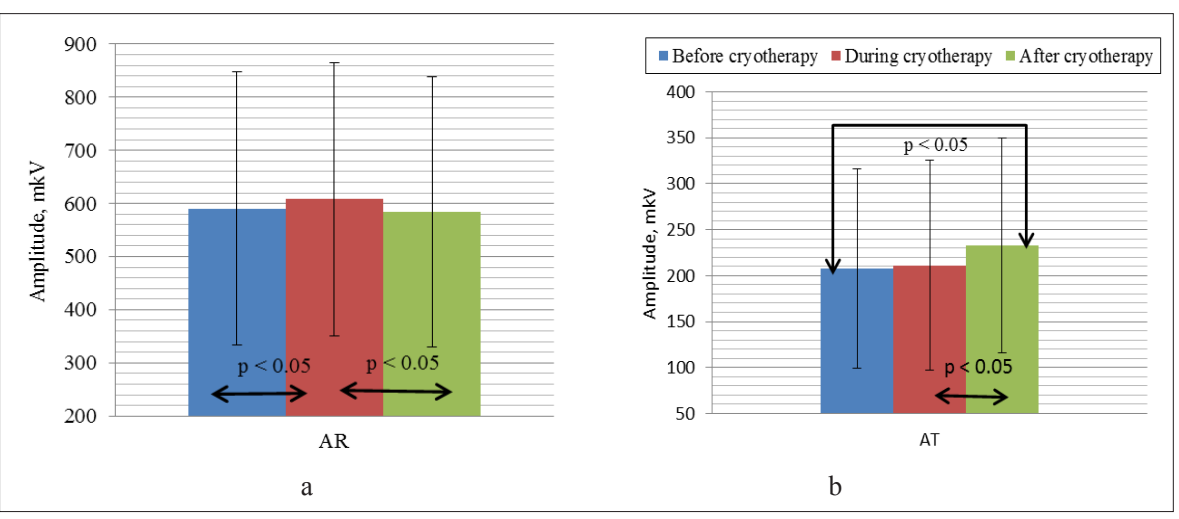

Figure 2. Changes in the amplitudes of ECG parameters during whole-body cryotherapy
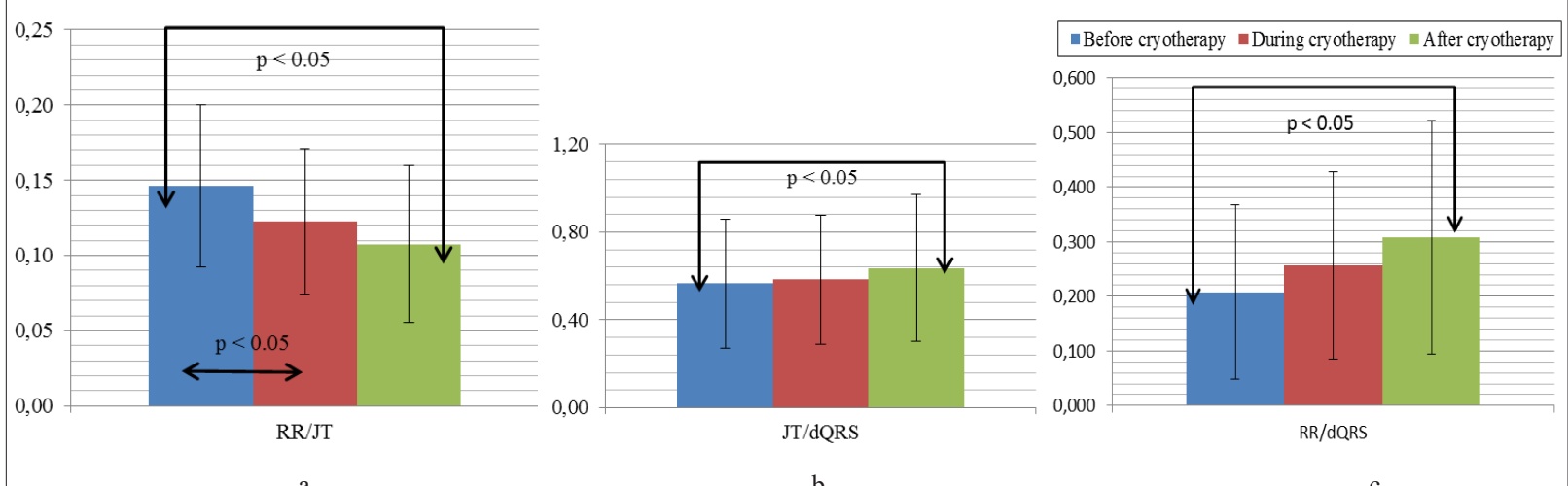

a

Figure 3. Changes in the concanetanations of ECG parameters (intervals) 


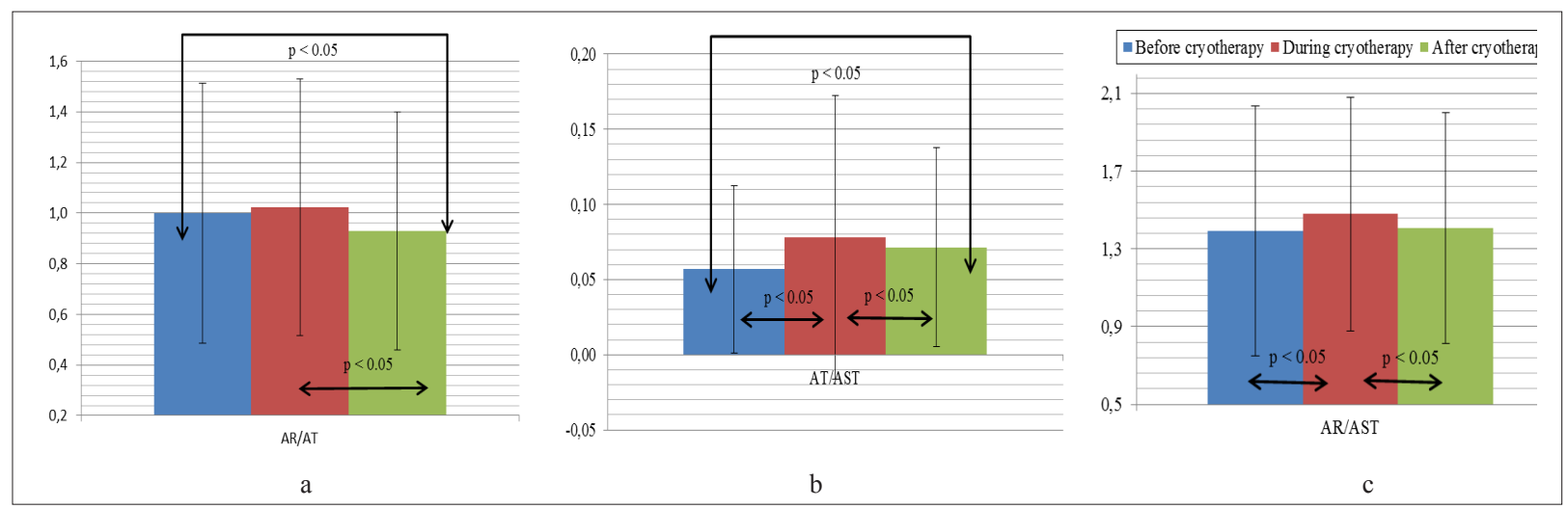

Figure 4. Changes in the concanetanations of ECG parameters (amplitudes)

values, increased during the recovery period (AT3) and statistically significantly $(\mathrm{p}<0.05)$ differed from the initial T-wave amplitude value (AT1) (Figure 2 b). Significant ST segment depression was not observed in any of ECG registration stages $(\mathrm{p}>0.05)$.

Statistically significant arterial blood pressure increase during cryotherapy procedure was observed. Systolic blood pressure increased from $129 \pm 17.33 \mathrm{mmHg}$ before cryotherapy procedure, to $139.00 \pm 23.45 \mathrm{mmHg}$ after it, diastolic - from $87.85 \pm 10.15 \mathrm{mmHg}$ to $90.33 \pm 9.40 \mathrm{mmHg}$ $(\mathrm{p}<0.05)$.

To evaluate adaptive reactions of the body with inter-parametric concatenations (dimensionless values) is more important. These showed adaptive processes and intersystem communications taking place at various levels in the body.

All concatenations of durational parameters changed during cryotherapy procedure and statistically significant changes occurred during the recovery period soon after the procedure. Parameters RR/JT concatenation changes occurred sooner - statistically significant differences $(\mathrm{p}<0.05)$ occurred during the procedure and remained during the recovery period after it (Figure 3 a). JT/QRS and RR/QRS parametric concatenations changed gradually and statistically significant differences were observed between the initial and recovery period values of these concatenations $(\mathrm{p}<0.05)$ (Figure $3 \mathrm{~b}, \mathrm{c})$.

Concatenations of amplitude parameters changed differently. AR/AT concatenation numeric value increased during the cryotherapy procedure and significantly decreased after it, statistically significant differences were observed between AR/AT concatenation during the procedure and soon after it, as well as the values between original AR/AT and AR/AT of the recovery period $(\mathrm{p}<0.05)$ (Figure 4 a). AT/AST concatenation changed through all measured periods; significant differences were between all three pairs of concatenations: AT/AST1 -AT/AST2, AT/AST2AT/AST3 and AT/AST1-AT/AST3 $(\mathrm{p}<0.05)$ (Figure 4 b). AR/AST concatenation changed during the procedure, and recovered its initial state soon after it $(p<0.05)$ so there were no differences between the initial original and final AR/AST values $(\mathrm{p}>0.05)$ (Figure $4 \mathrm{c}$ ).

The hypothesis $\mathrm{H}_{\mathrm{o}}$ was rejected - whole body cryotherapy caused changes in ECG parameters and their concatenations.

\section{DISCUSSION}

Cardiovascular system reaction to shortterm stress caused by extreme cold attracts attention of many researchers. In most cases they study variations in heart rate changes before the cryotherapy procedure and at different periods after it (by registering one - two standard lead ECG, ECG using 24h Holter's method). Usually analysis of ST segment, RR variability, systolic and diastolic blood pressure before cryotherapy and after the procedure, echoscopically assessing left ventricular ejection fraction before cryotherapy and after it are performed. There are no data available in literature how these parameters change during the procedure. Some authors point out that whole body cryotherapy does not cause any changes in hemodynamic parameters, such as heart rate, systolic and diastolic blood pressure (Sieron, Cieslar, 2007 b; Тетюра, 2009). Other authors shows increased arterial blood pressure (Lyakh et al., 2009; Lubkowska, Szygula, 2010), 
decreased heart rate and increased stroke volume (SV), systolic index (SI) (Zalewski et al., 2011).

It is very difficult to systemize the results from various sources because the authors often confuse terms of cryotherapy and hypothermia, they often compare the results obtained in cold water with the results, obtained in cryogenic gases. The research of effects of cryotherapy shows, that optimal cryogenic temperature is $-130,-160^{\circ} \mathrm{C}$. Temperature higher than $-120^{\circ} \mathrm{C}$ does not show any cryotherapeutic effect (Апрелева, Баранов, 2007). The fact that changes of hemodynamic parameters during cryotherapy were not seen in investigations can be explained by not enough low temperature (which has no cryotherapeutic effect) used for the procedure or too low sensitivity of recorded the parameters and analysis methods used.

Personal cryosauna that we used in our research meets temperature requirements (average temperature is $-160^{\circ} \mathrm{C}$ ), and computerized ECG analysis system "Kaunas-Load" registers 12-lead ECG. Special filters installed in the program cancels all electrostatic, respiratory and movement caused noises. High sensitivity electronic ruler allows measuring all important ECG parameters and their concatenations, variability of these parameters, etc. precisely. On the basis on the changes in these parameters and their concatenations we can evaluate the organism responsive reactions to impacts of cryotherapy procedures.

According to the duration parameters changes we can suggest that the body reaction to extremely cold environment already starts during the procedure, although statistically significant differences in most parameters only become apparent during the recovery period after the procedure. Regulatory system reacts at all levels systemic (RR), sub systemic (JT) and the organ (dQRS) levels. Amplitudinal parameters change slightly differently. R-wave amplitude increases during the procedure, possibly due to peripheral resistance and systolic index increase. $\mathrm{T}$ wave amplitude significantly changes during the recovery and that shows that cryotherapy induced metabolic processes changing in myocardium. There are no statistically significant ST-segment amplitude changes during cryotherapy, so in terms of coronary circulation processes the procedure is safe. The increase of blood pressure during cryotherapy procedure is reported by many researchers, but critical threshold for arterial blood pressure increase reported is no more than $20 \mathrm{mmHg}$ (Lyakh et al., 2009) and it is completely normal that stress, caused by thermal procedure, increases ABP.

The change between parametric concatenations helps to assess body complexity and the main functional links even more than parameters alone. Changes in duration parameter concatenations show that regulatory (neurohumoral) system reacts in the first place at the systemic level. Significant $\mathrm{RR} / \mathrm{JT}$ concatenation changes have been observed during the procedure. Decrease of RR/JT values represents decrease in systems complexity, i. e. increase of interaction between regulatory and supplying systems at the level of the human body. Increasing of JT/QRS and RR/QRS values indicate the increase of adaptation processes at organ and cell levels. Adaptive responses, activated during the procedure become even more pronounced during recovery period (Figure $3 \mathrm{a}, \mathrm{b}, \mathrm{c}$ ).

According to the changes in the amplitude parameter concatenations, we can conclude that respiratory function improves after cryotherapy procedure (changes of AR/AT concatenation) (Figure 4 a). Changes of blood circulation in organs were observed during all stages, i.e. circulation changes during the procedure and lasts during recovery after it (AT/ST) (Figure 4 b). Changes in the respiratory system and coronary hemodynamic were observed only during the procedure and their values returned to baseline levels after it (AR/AST) (Figure $4 \mathrm{c}$ ).

\section{CONCLUSIONS AND PERSPECTIVES}

Whole body cryotherapy - short term but intense irritation of the body surface with extremely low temperature - causes sharp adaptive reactions at all levels of an organism. These reactions can be detected by original ECG analysis method "Kaunas -Load" during all cryogenic exposure periods and the data obtained by this method can help explain human organism as an open adaptive complex system.

The obtained data confirm the data presented by other researchers, the safety of the procedure, and they reveal a deep interconnection between interactions not studied before, which determines positive therapeutic effects of whole body cryotherapy. 
Cryotherapy affects the human body at the regulatory level, cardio metabolism level and organizational level of the heart itself - the organism reacts like a unified complexity system at all its fractal levels.
This method can be used to evaluate the effects of other therapeutic procedures on the human body widely used in health resort medicine (balneotherapy, peloidotherapy).

\title{
REFERENCES
}

Berškienè K. (2010). Elektrokardiografinių signalų parametrų dinaminių sąsajų analizè: daktaro disertacija. Kauno technologijos universitetas.

Berskiene, K., Lukosevicius, A., Jarusevicius, G. et al. (2009). Analysis of Dynamical Interrelations of Electrocardiogram Parameters: Electronics and Electrical Engineering. Technologija, 7 (95), 95-98.

Erdi, P. (2008). Complexity Explained. Springer.

Georg Thieme Verlag KG. Stutgart-New York DOI $10.1055 / \mathrm{s}-2003-814868$.

Joch W., Ückert S. (2004). Auswirkungen der Ganzkörperkälte von $-110^{\circ}$ Celsius auf die Herzfrequenz bei Ausdauerbelastungen und in Ruhe. Physikalische Medizin - Rehabititationsmedizin - Kurortmedizin, 14, 146-150.

Lubkowska, A., Szygula, Z. (2010). Changes of blood pressure with compensatory heart rate decrease and in the level of aerobic capacity in response to repeated whole-body cryostimulation in normotensive, young and physically active men. International Journal of Occupational Medicine and Environmental Health, 23 (4), 367-375.

Lyakh, Yu. E., Panchenko, O. A., Tetyura, S. M. Antonova, V. O. (2009). The estimation of extremely low temperatures influence on patients' organism during the whole body air cryotherapy. University Clinic, 5 (1-2), 78-82.
Sieron, A., Cieslar, G. (2007 a). Krioterapia - leczenie zimniem. Podstawy teoretyczne, efekty biologiczne, zastosowania kliniczne. Bielsko-Biala: $\alpha$-medica press. P. 16.

Sieron, A., Cieslar, G. (2007 b). Krioterapia - leczenie zimniem. Podstawy teoretyczne, efekty biologiczne, zastosowania kliniczne. Bielsko-Biala: $\alpha$-medica press. P. 103-108.

Vainoras, A., Daunoravičienè, A., Šiupšinskas, L. et al. (2008). Kineziologija: mokomoji knyga. Kaunas: Vitae litera. P. 20.

Zalewski, P., Klawe, J., Tafil-Klawe, M. et al. (2011). Wplyw krioterapii ogolnoustrojowej na uklad sercowonaczyniowy i procesy termoregulacji u osob zdrowych. Acta Balneologica. Tom LIII, 2, 84-95.

Žemaitytė, M. D. (1997). Širdies ritmo autonominis reguliavimas: mechanizmai, vertinimas, klinikine reikšmé. Palanga.

Апрелева, А. В., Баранов, А. Ю. (2007). Общая криотерапия как новый метод интенсификации тренировочного процесса. Учёнье записки, 8 (30), 8-14.

Тетюра, С. М., Антонова, В. О. (2009). Влияние экстремальной криотерапии на функциональное состояние сердечно-сосудистой системы человека. Internet link: http://www.nbuv.gov.ua/portal/Chem_Biol/ pekm/2009_2/072.pdf

\section{BENDROJI KRIOTERAPIJA IR ORGANIZMO ADAPTACINÉS REAKCIJOS KOMPLEKSINIŲ SISTEMŲ TEORIJOS POŽIŪRIU}

\author{
Giedrẻ Taletavičiene் $\dot{1}^{1,2}$, Alfonsas Vainoras ${ }^{2}$, Kristina Berškiene் $\dot{2}^{2}$, Kęstutis Ramanauskas ${ }^{3}$ \\ $U A B$,Druskininku sveikatinimo ir poilsio centras AQUA“, padalinys Druskininku gydykla, \\ Druskininkai, Lietuva \\ Lietuvos sveikatos mokslu universitetas ${ }^{2}$, Kaunas, Lietuva \\ VŚt ,Lietuvos kurortologijos tyrimu centras "3, Vilnius, Lietuva
}

\section{SANTRAUKA}

Tyrimo pagrindimas ir hipoteze. Tyrimu buvo gilinamasi i įvairių EKG rodmenų ir jų sąsajų pokyčius bendrosios krioterapijos procedūros metu.

Tikslas - ištirti ir įvertinti žmogaus organizmo sistemų kompleksiškumą analizuojant įvairių EKG rodmenų ir jų sąsajų pokyčius bendrosios krioterapijos procedūros metu. 